\title{
N-propylpyridinium Chloride Silsesquioxane Polymer Film on Graphite: Electrochemical Study of a Hexacyanoferrate (II) Ion Immobilized Electrode for Oxidation of Ascorbic Acid
}

\author{
Rení V. S. Alfaya, Yoshitaka Gushikem* and Antonio A. S. Alfaya \\ Instituto de Química, Universidade Estadual de Campinas, CP 6154, 13083-970 Campinas-SP, Brazil
}

\begin{abstract}
Uma superfície de grafite bem polida foi recoberta com um filme fino do polímero cloreto de n-propilpiridínio silsesquioxano. Sobre o filme do polímero fortemente aderido ao grafite, a espécie eletroativa $\left[\mathrm{Fe}(\mathrm{CN})_{6}\right]^{4-}$ foi adsorvida por meio de uma reação de troca iônica. O eletrodo resultante, $\left(\mathrm{graph} / \mathrm{SiPy}{ }^{+}\right)_{4}\left[\mathrm{Fe}(\mathrm{CN})_{6}\right]^{4-}\left(\right.$ graph $=$ grafite e $\mathrm{SiPy}{ }^{+}$representa o polímero N-propilpiridinio silsesquioxano), mostrou-se quimicamente muito estável e foi utilizado para oxidar eletrocataliticamente o ácido ascórbico em solução de $\mathrm{KCl}$ 0,1 $\mathrm{mol} \mathrm{dm}^{-3}$, em pH entre 4,5 e 6,5. O eletrodo foi utilizado para determinar vitamina $\mathrm{C}$ em tabletes e em sucos de laranja processados. Os resultados mostraram uma boa concordância com aqueles obtidos utilizando o método padrão de titulação com 2,6-diclorofenolindofenol.
\end{abstract}

A well polished graphite surface was coated with a thin film of N-propylpyridinium chloride silsesquioxane polymer. On to the strongly graphite-adhered polymer film the electroactive species $\left[\mathrm{Fe}(\mathrm{CN})_{6}\right]^{4-}$ was adsorbed by means of an ion exchange reaction. The resulting electrode (graph/ $\left.\mathrm{SiPy}^{+}\right)_{4}\left[\mathrm{Fe}(\mathrm{CN})_{6}\right]^{4-}\left(\right.$ graph $=$ graphite and $\mathrm{SiPy}{ }^{+}$represents the N-propilpyridinium silsesquioxane polymer) was chemically very stable and was used to electrocatalytically oxidize ascorbic acid in solution ( $\mathrm{pH}$ between 4.5-6.5) in $0.1 \mathrm{~mol} \mathrm{dm}^{-3} \mathrm{KCl}$. The electrode was used to determine vitamin C in tablets and in processed orange juices. The results were in accord with those obtained by using the standard 2,6-dichlorophenolindophenol titration method.

Keywords: N-propylpyridinium chloride silsesquioxane polymer-coated graphite electrode, hexacyanoferrate(II) ion, electroacatalytic oxidation, amperometric determination, ascorbic acid

\section{Introduction}

N-propylpyridiniumchloride silsesquioxane (Figure 1) is a new water soluble polymer ${ }^{1}$ whose most important characteristic is its capacity for forming a stable thin film on substrate surfaces such as aluminum oxide, celullose fibers, silica gel or glass surfaces 2,3 . The polymer is a strong anionic exchanger and since the immobilized counterion is the pyridinium ion, the exchange reaction does not depend on the solution $\mathrm{pH}^{4}$. The strength with which an anionic species is adsorbed and retained on the polymer surface depends essentially on its affinity coefficient for the solid phase i.e. the ratio between the adsorbate concentration on the solid phase and in solution phase ${ }^{5}$.

Considering the excellent capacity of this new anionic exchanger polymer for forming a thin film on the graphite surface, ferrocyanide ion was adsorbed on the resulting modifed surface by an ion exchange reaction, since it is known that propylpyridinium chloride groups are good ion exchangers and have high affinity for this ion 6 .

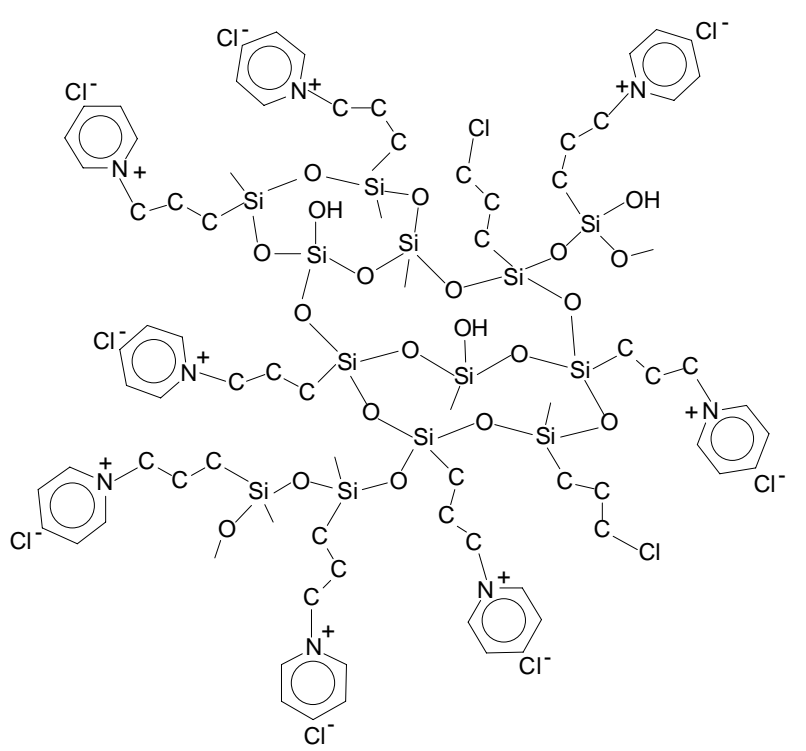

Figure 1. N-propylpyridinium chloride silsesquioxane polymer.

The electrochemical properties of this ion were investigated and applied in the electrocatalytic oxidation of 
ascorbic acid. Due to its importance in biochemical and biomedical processes, development of new methods of analyses by means of electrochemical sensors based on carbon paste modified electrodes $6-11$, carbon fiber ${ }^{12}$, glassy carbon ${ }^{13,14}$, tick-film carbon ${ }^{15}$ and polymercoated electrodes ${ }^{16-22}$ have been tested.

To probe the potential usefulness of the modified electrode as a chemical sensor, the studies were extended to analyze ascorbic acid in commercially available vitamin $\mathrm{C}$ tablets and in processed orange juices.

\section{Experimental}

The polymer 3-n-propylpyridiniumchloride silsesquioxane, referred to as $\mathrm{SiPy}^{+} \mathrm{Cl}$, was prepared according to the method described elsewhere ${ }^{1}$. Analytical grade potassium ferrocyanide and ascorbic acid were used as received without any previous purification.

\section{Polymercoated graphite}

An electrode was made by inserting, under pressure, a spectroscopically pure $8 \mathrm{~mm}$ diameter graphite cylinder in the hole of a Teflon bar with same internal diameter. The end of the graphite surface was polished and the clean surface was immersed in an aqueous solution of the polymer $\mathrm{SiPy}^{+} \mathrm{Cl}^{-}(5 \% \mathrm{w} / \mathrm{v})$ for $30 \mathrm{~min}$ and then dried at room atmosphere. The electrode, referred to as graph $/ \mathrm{SiPy}^{+} \mathrm{Cl}^{-}$, was immersed in a solution of potassium ferrocyanide $(20 \% \mathrm{~m} / \mathrm{v})$ for $10 \mathrm{~min}$ and then rinsed with pure water and dried. The resulting modified electrode is designated as $\left(\mathrm{graph} / \mathrm{SiPy}^{+}\right)_{4}\left[\mathrm{Fe}(\mathrm{CN})_{6}\right]^{4-}$.

\section{Electrochemicalmeasurements}

The electrochemical measurements were made by immersing the prepared electrode, as described above, in a cell with $0.1 \mathrm{~mol} \mathrm{dm}^{-3} \mathrm{KCl}$ solution by using a platinum wire as the counter electrode and SCE as the reference electrode. Cyclic voltammetry measurements were made by sweeping the potential between -0.2 and $0.5 \mathrm{~V}$ at a scan rate of $20 \mathrm{mV} \mathrm{s}^{-1}$.

In amperometric detection successive volumes of 0.01 mol dm$~^{-3}$ ascorbic acid were added in an electrochemical cell filled with $20 \mathrm{~cm}^{3}$ of $0.1 \mathrm{~mol} \mathrm{dm}^{-3} \mathrm{KCl}$ solution and at a fixed potential of $0.2 \mathrm{~V}$, at $\mathrm{pH} 5.5$. All the electrochemical measurements were carried out under pure argon atmosphere.

Ascorbic acid in real samples (vitamin $\mathrm{C}$ tablets) from three different suppliers were analyzed. The tablets $(\sim 4 \mathrm{~g})$ were dissolved in bidistilled water and the volume completed to $500 \mathrm{~cm}^{3}$ (solution A). The amperometric curves were obtained by adding successive aliquots of $200 \mu \mathrm{dm}^{3}$ of solution A into a cell filled with $20 \mathrm{~cm}^{3}$ of $0.1 \mathrm{~mol} \mathrm{dm}^{-3}$ $\mathrm{KCl}$ solution at $\mathrm{pH}$ 5.5. The observed current against time plot was compared with that obtained for standard ascorbic acid solution. In processed juices, vitamin $\mathrm{C}$ was determined by using similar procedure.

Vitamin $\mathrm{C}$ in tablets and in juices was also determined by the standard volumetric technique by using the reagent 2,6-dichlorophenolindophenol (dpip) ${ }^{23-25}$.

\section{Results and Discussion}

The hexacyanoferrate (II) ion is bound to the electrode surface by an electrostatic interaction and gives a redox pair at a midpoint potential $\mathrm{E}_{\mathrm{m}}=0.14 \mathrm{~V}\left(\mathrm{E}_{\mathrm{m}}=\mathrm{E}_{\mathrm{pa}}+\mathrm{E}_{\mathrm{pc}}\right) / 2$, where $\mathrm{E}_{\mathrm{pa}}$ and $\mathrm{E}_{\mathrm{pc}}$ are the anodic and the cathodic peak potentials, respectively] in $0.1 \mathrm{~mol} \mathrm{dm}^{-3} \mathrm{KCl}$ solution at $\mathrm{pH} 5.5$ (Figure 2c). By integrating the area under the anodic or cathodic curves and considering that the geometric area of the electrode is $0.5 \mathrm{~cm}^{2}$, the quantity of estimated ferrocyanide ion

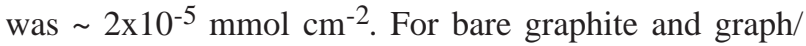
$\mathrm{SiPy}^{+} \mathrm{Cl}^{-}$electrodes no redox pair in the range of the potential swept was observed (Figures 2, a and b, respectively).

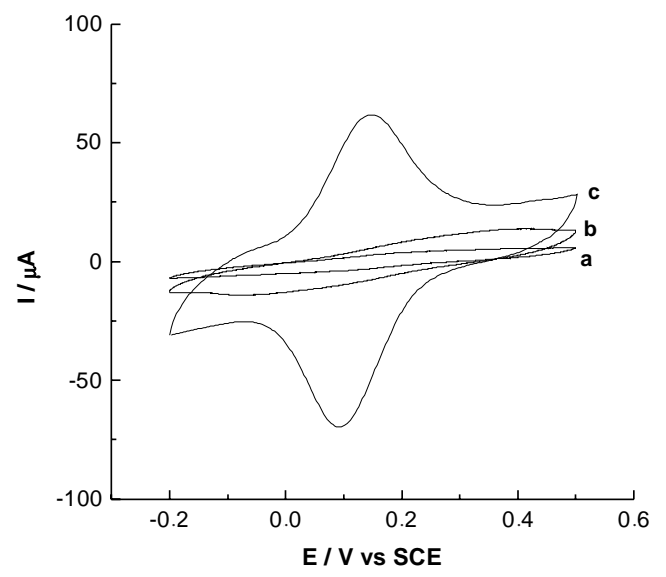

Figure 2. Cyclic voltammetry curves obtained by using the following electrodes of: (a) graphite, (b) graph/SiPy $+\mathrm{Cl}^{-}$and (c) (graph/ $\left.\mathrm{SiPy}^{+}\right)_{4}\left[\mathrm{Fe}(\mathrm{CN})_{6}\right]^{4-}$. Scan rate of $20 \mathrm{mV} \mathrm{s}^{-1}, \mathrm{pH} 5.5$.

Figure 3 shows the influence of the solution $\mathrm{pH}$ on $\mathrm{E}_{\mathrm{m}}$. Between $\mathrm{pH} 4.5$ and 6.5 the $\mathrm{E}_{\mathrm{m}}$ remained nearly constant and increased at $\mathrm{pH}$ values lower than 4 . An explanation for such behavior is presumably related to the tendency of the hexacyanoferrate (II) ion to form a stable ion pair with $\mathrm{H}^{+}$with an association constant ${ }^{30} \log \mathrm{K}_{\mathrm{a}}=4.28$. Such increase of midpoint potential was already observed for an electrode of $\mathrm{SiO}_{2} / \mathrm{TiO}_{2} /\left[\mathrm{Fe}(\mathrm{CN})_{6}\right]^{4-}$ where hexacyanoferrate (II) is strongly adsorbed on the titanium oxide surface, ${ }^{\circ} \mathrm{TiOH}_{2}{ }^{+}\left[\mathrm{Fe}\left(\mathrm{CN}_{6}\right)_{6}\right]^{4-}$ by electrostatic interaction ${ }^{26}$ $\left(\equiv \mathrm{TiOH}_{2}{ }^{+}\right.$stands for protonated hydrous Ti(IV) oxide grafted to a silica gel surface). 


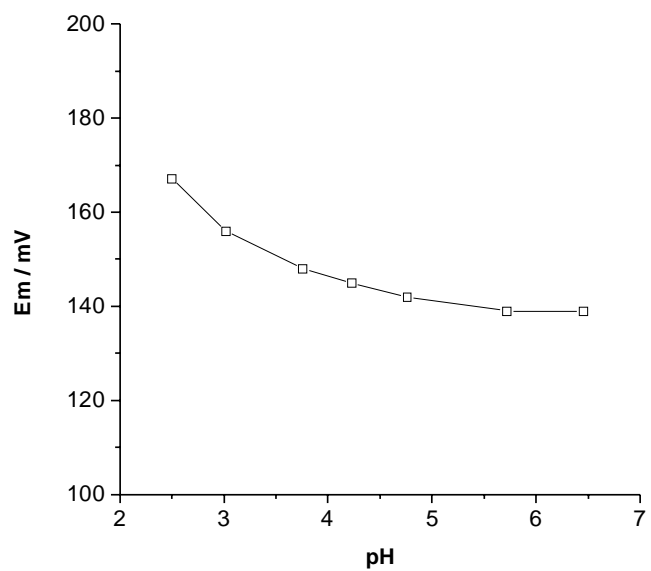

Figure 3. Influence of the solution $\mathrm{pH}$ on the midpoint potential, $\mathrm{E}_{\mathrm{pa}}$, for $\left(\mathrm{graph} / \mathrm{SiPy}^{+}\right)_{4}\left[\mathrm{Fe}(\mathrm{CN})_{6}\right]^{4-}$ in $0.1 \mathrm{~mol} \mathrm{dm}^{-3} \mathrm{KCl}$ solution, scan rate of $20 \mathrm{mV} \mathrm{s}^{-1}$ and ascorbic acid concentration of $1 \times 10^{-3} \mathrm{~mol} \mathrm{dm}^{-3}$.

In order to check the stabiltiy of the electrode under exhaustive operation conditions, the anodic and the cathodic peak current intensities were measured against the number of oxidation-reduction potential cycles (Figure 4). Upon cycling the potential between -0.2 and $0.5 \mathrm{~V}$ at a sweeping velocity of $20 \mathrm{mV} \mathrm{s}^{-1}$, the anodic and cathodic peak current intensities did not show any significant decrease resulting from release of the electroactive species to the solution phase at the end of 60 redox cycles. Such degree of adherence on the surface is presumably related to a high affinity coefficient of the hexacyanoferrate (II) ion to the immobilized pyrydinium ion in the solid phase.

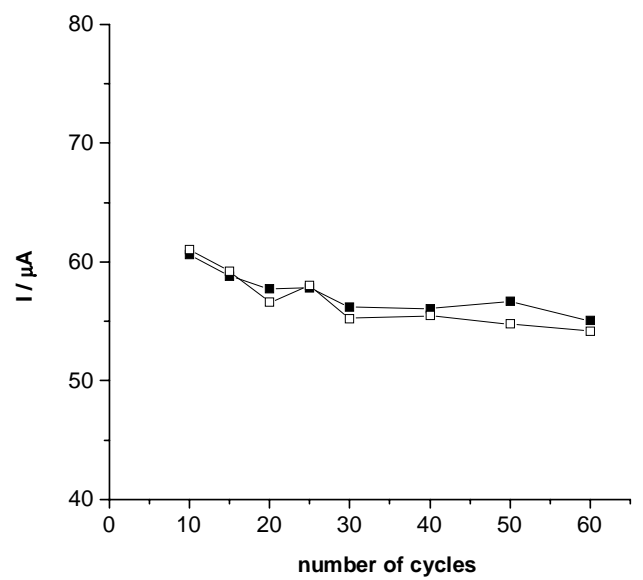

Figure 4. Peak currents for $(\mathrm{graph} / \mathrm{SiPy})_{4}\left[\mathrm{Fe}(\mathrm{CN})_{6}\right]^{4-}$ as function of number of redox cycles under scan rate of $20 \mathrm{mV} \mathrm{s}^{-1}$ in $0.1 \mathrm{~mol} \mathrm{dm}^{-3}$ $\mathrm{KCl}$ solution. ( $\square$ ) cathodic peak current, $(\square)$ anodic peak current

\section{Oxidation of the ascorbic acid}

Figure 5 shows the ascorbic acid oxidation on the $\left(\text { graph } / \mathrm{SiPy}^{+}\right)_{4}\left[\mathrm{Fe}(\mathrm{CN})_{6}\right]^{4-}$ electrode surface. The cyclic voltammetry curve in the presence of $1.0 \times 10^{-3} \mathrm{~mol} \mathrm{dm}^{-3}$ ascorbic acid solution ( $\mathrm{pH}$ 5.5) shows a considerable enhancement of the electrode anodic peak current at $0.19 \mathrm{~V}$ (curve c) in comparison with the current peak in absence of the acid (curve b). On the bare electrode graph $/ \mathrm{SiPy}^{+} \mathrm{Cl}^{-}$ (curve a) no current is observed for $1.0 \times 10^{-3} \mathrm{~mol} \mathrm{dm}^{-3}$ ascorbic acid solution ( $\mathrm{pH}$ 5.5). The acid oxidation reactions at the solid-solution interface can be described by the following reactions:

$$
\begin{aligned}
& 2\left(\text { graph } / \mathrm{SiPy}^{+}\right)_{4} /\left[\mathrm{Fe}^{\mathrm{II}}(\mathrm{CN})_{6}\right]^{4-} \rightarrow \\
& 2\left(\text { graph } / \mathrm{SiPy}^{+}\right)_{4} /\left[\mathrm{Fe}^{\mathrm{III}}(\mathrm{CN})_{6}\right]^{3-}+2 \mathrm{e}^{-} \\
& 2\left(\mathrm{graph} / \mathrm{SiPy}^{+}\right)_{4} /\left[\mathrm{Fe}^{\mathrm{III}}(\mathrm{CN})_{6}\right]^{3-}+\mathrm{H}_{2} \mathrm{AA} \rightarrow \\
& 2\left(\text { graph } / \mathrm{SiPy}^{+}\right)_{4} /\left[\mathrm{Fe}^{\mathrm{II}}(\mathrm{CN})_{6}\right]^{4-}+2 \mathrm{AA}+2 \mathrm{H}^{+}
\end{aligned}
$$

where $\mathrm{H}_{2} \mathrm{AA}$ is the ascorbic acid and AA the dehydroascorbic acid.

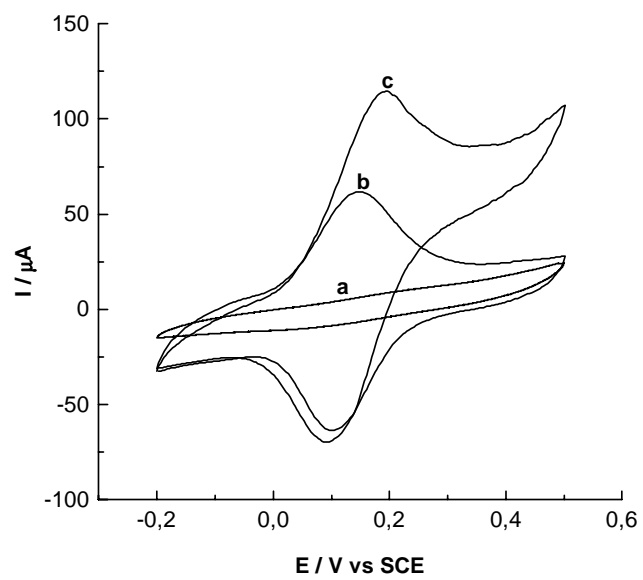

Figure 5. Cyclic voltammetry curves in $0.1 \mathrm{~mol} \mathrm{dm}^{-3} \mathrm{KCl}$ solutions, $\mathrm{pH} 5.5$ and scan rates of $20 \mathrm{mV} \mathrm{s}^{-1}$ : (a) in the presence of ascorbic acid $1 \times 10^{-3} \mathrm{~mol} \mathrm{dm}^{-3}$ on bare electrode surface, graph/ $\mathrm{SiPyCl}$; (b) in the absence of ascorbic acid on $\left(\mathrm{graph} / \mathrm{SiPy}^{+}\right)_{4}$ $\left[\mathrm{Fe}(\mathrm{CN})_{6}\right]^{4-}$ electrode surface and (c) on $\left(\mathrm{graph} / \mathrm{SiPy}^{+}\right)_{4}$ $\left[\mathrm{Fe}(\mathrm{CN})_{6}\right]^{4-}$ electrode surface in the presence of ascorbic acid $1 \times 10^{-3} \mathrm{~mol} \mathrm{dm}^{-3}$.

\section{Amperometric detection}

Figure 6a shows the amperometric curve obtained upon addition of the ascorbic acid into an electrochemical cell at a fixed $E_{p a}=0.2 \mathrm{~V}$. It is noteworthy that the response time is very fast and there is no indication that the product is being adsorbed on the electrode surface during the experiment. Such adsorption could interfere on the electrode response, by suppressing the signal. Figure $6 \mathrm{~b}$ shows the plot of the current peak against ascorbic acid concentrations. A linear correlation for concentrations of the acid between $0.25 \times 10^{-4}$ and $2.5 \times 10^{-4} \mathrm{~mol} \mathrm{dm}^{-3}$ is observed with a detection limit of $0.25 \times 10^{-4}$ mol. $\mathrm{dm}^{-3}$ and sensitivity of $0,25 \times 10^{-5} \mathrm{~mol} \mathrm{dm}^{-3}$. Therefore, the present electrode has a potential use as sensor for ascorbic acid. 
Table 1. Amount of vitamin $\mathrm{C}$ in tablets and in processed juices from different suppliers.

\begin{tabular}{ccccc}
\hline Samples & $\begin{array}{c}\text { Declared } \\
\text { amount } / \mathrm{g}\end{array}$ & $\begin{array}{c}\text { Titration } \\
\text { with dpip /g }\end{array}$ & $\begin{array}{c}\text { Amperometry } \\
(\Delta) / \mathrm{g}\end{array}$ & $\begin{array}{c}\text { Relative } \\
\text { Error } \%\end{array}$ \\
\hline tablet A & $1.0^{\mathrm{a}}$ & $1.002 \pm 0.001$ & $1.02 \pm 0.02$ & 1.8 \\
tablet B & $1.0^{\mathrm{a}}$ & $0.996 \pm 0.001$ & $1.04 \pm 0.02$ & 4.4 \\
tablet C & $1.0^{\mathrm{a}}$ & $1.003 \pm 0.002$ & $1.08 \pm 0.03$ & 7.1 \\
juice A & - & $0.342 \pm 0.003 \mathrm{~b}$ & $0.36 \pm 0.01$ & 5.3 \\
juice B & - & $0.235 \pm 0.002 \mathrm{~b}$ & $0.25 \pm 0.01$ & 6.4 \\
\hline
\end{tabular}

${ }^{\mathrm{a}}$ weight of the tablet $4 \mathrm{~g}$; ${ }^{\mathrm{b}}$ per liter of juice; $(\Delta)$ Assay values represent the average of five $(\mathrm{n}=5)$ determinations per sample with a confidence level of $95 \%$.

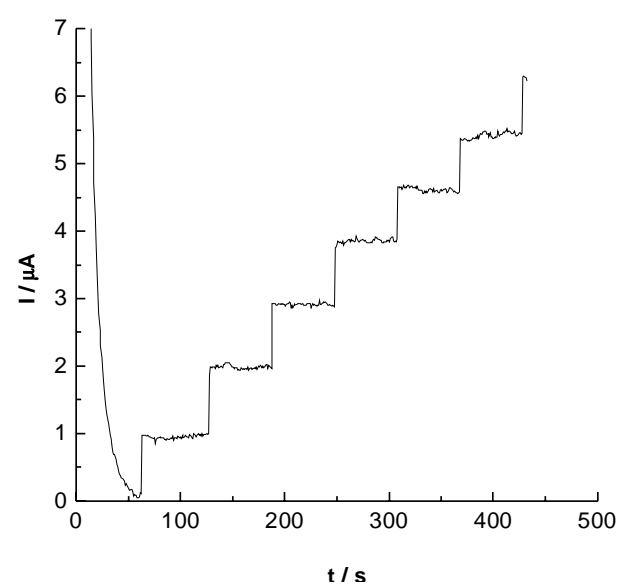

(a)

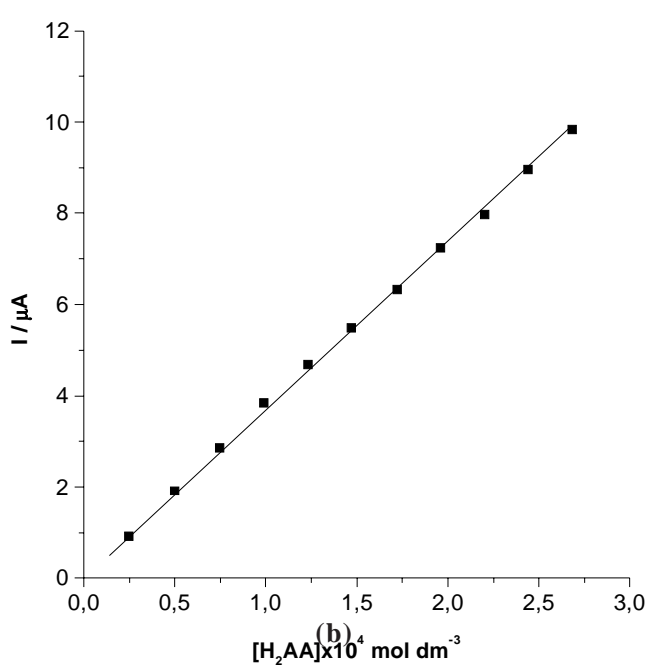

Figure 6. Chronoamperometry study for $\left(\mathrm{graph} / \mathrm{SiPy}^{+}\right)_{4}\left[\mathrm{Fe}(\mathrm{CN})_{6}\right]^{4-}$ in $0.1 \mathrm{~mol} \mathrm{dm}^{-3} \mathrm{KCl}$ solution. (a) chronoamperogram obtained by successive addition of $50 \mu \mathrm{dm}^{3}$ ascorbic acid $0.01 \mathrm{~mol} \mathrm{dm}^{-3}$ into an electrochemical cell containing $20 \mathrm{~cm}^{3} 0.1 \mathrm{~mol} \mathrm{dm}^{-3} \mathrm{KCl}$ solution at $\mathrm{pH} 5.5$, (b) Plot of anodic peak current $\mathrm{I}_{\mathrm{pa}}$ against ascorbic acid concentration.

\section{Determination of ascorbic acidin real samples}

The results of the analyses of vitamin $\mathrm{C}$ in tablets and juices (an average of five determinations) obtained using the electrode are presented in Table 1 . The values found are compared with those obtained following the recommended ascorbic assay procedure by using the dpip reagent ${ }^{23}$. The amperometric measurements results are found with $95 \%$ confidence level and by applying the paired t-test a minimum with $95 \%$ confidence.

\section{Conclusions}

The electrode $\left(\mathrm{graph} / \mathrm{SiPy}^{+}\right)_{4} /\left[\mathrm{Fe}^{\mathrm{II}}(\mathrm{CN})_{6}\right]^{4-}$ was stable under the operation conditions. The results obtained by using the present electrode are very good considering that other chemical species which could be present, especially in the processed juices, did not interfere in the results. The advantages of using the present electrode are the small time dedicated to the analytical procedure and the fact that it is easily prepared and regenerated. The electrode was relatively sensitive in detecting, using the chronoamperometry technique, a concentration limit of $0.25 \times 10^{-4} \mathrm{~mol} \mathrm{dm}^{-3}$ ascorbic acid.

\section{Acknowledgments}

Y. G. is indebted to FAPESP and PRONEX for financial support; R. V. S. A. and A. A. S. A. are indebted to CAPES/ PICD and CNPq for a fellowship

\section{References}

1. Gushikem, Y.; Alfaya, R. V. S.; Alfaya, A. A. S., 1998, Braz. Pat., INPI 9803053-1.

2. Alfaya, R. V. S.; Gushikem, Y. J. Colloid Interface Sci., 1999, 213, 438.

3. Fujiwara S. T.; Gushikem Y.; Alfaya, R. V. S., Colloid Surf. A, Phys. Chem. Eng. Aspects, 2000 (in press).

4. Oyama N.; Shimomura, T.; Shigehara, K.; Anson, F. C. J. Electroanal. Chem. 1980, 112, 271.

5. Gushikem, Y.; Moreira, W. C. Colloids Surf. 1987, $25,155$.

6. Lorencetti, L. L.; Gushikem, Y. J. Braz. Chem. Soc. 1993, 4, 88 .

7. Pessôa, C. A.; Gushikem, Y.; Kubota, L. T. Electroanal. 1997, 9, 800 . 
8. Andreotti, E. I. S.; Gushikem, Y.; Kubota, L. T. J. Braz. Chem. Soc. 1992, 3, 21.

9. Dayton, M. A.; Brown, J. C.; Stutts, K. J.; Wightman, R. M. Anal. Chem. 1980, 52, 946.

10. Ravichandran, K.; Baldwin, R. P. Anal. Chem. 1983, $55,1586$.

11. Wightman, R. M.; Deakin, M. R.; Kovach, P. M.;Kuhr, W. G.; Stutts, K. J. J. Electrochem. Soc. 1984, 131, 1578.

12. Gonon, F. G.; Fombarlet, C. M.; Buda, M. J.; Pujol, J. F. Anal. Chem. 1981, 53, 1386.

13. Gomathi, H.; Rao, G. P. J. J. Electroanal. Chem. 1983 , 154, 121.

14. Zac, J.; Kuwana, T. J. Am. Chem. Soc. 1982, 104, 5514.

15. Xing, X.; Tan, T. C.; Shao, M.; Liu, C. C. Electroanal. 1992, 4, 191.

16. Lyons, M. E. G.; Breen, W.; Cassidy, J. J. Chem. Soc. Faraday Trans. 1991, 87, 115.
17. Kuo, K. N.; Murray, R. W. J. Electroanal. Chem. 1982 , $131,37$.

18. Miller, C. J.; Majda, M. Anal. Chem. 1988, 60, 1168. 19. Facci, J.; Murray, R. W. Anal. Chem. 1982, 54, 772.

20. Dautartas, M. F.; Evans, J. F. J. Electroanal. Chem. 1980, 109, 301.

21. Mao, H.; Pickup, P. G. J. Electroanal. Chem. 1989, 265, 127.

22. Saraceno, R. A.; Pack, P. G.; Ewing, A. G. J. Electroanal. Chem. 1986, 197, 265.

23. Freed, M. Methods of Vitamin Assay, Interscience, $3^{\text {th }}$ ed, New York, 1966.

24. Karayannis, M. I. Anal. Chim. Acta 1975, 76, 121.

25. Lindquist, J. Analyst, 1975, 100, 339.

26. Kubota, L. T.; Gushikem, Y. Electrochim. Acta. 1992 , 37, 2477.

27. Sillen L. G.; Martell, A.E. Stability Constants of Metal-Ion Complexes, The Chemical Society, London, 1971, Supplement $N^{o}$ 1, p. 49.

Received: July 12, 1999.

FAPESP helped in meeting the publication costs of this article. 